\title{
The Management of Mina Salt Ponds, Tradition, and Economy's Rhythm of the Community in Madura Island
}

\author{
$1^{\text {st }}$ Sumarmi \\ Faculty of Social Sciences \\ Universitas Negeri Malang \\ Malang, Indonesia \\ sumarmi.fis@um.ac.id \\ $2^{\text {nd }}$ Syamsul Bachri \\ Faculty of Social Sciences \\ Universitas Negeri Malang \\ Malang, Indonesia
}

\author{
$3^{\text {rd }}$ Listyo Yuda Irawan \\ Faculty of Social Sciences \\ Universitas Negeri Malang \\ Malang, Indonesia \\ $4^{\text {th }}$ Elya Kurniawati \\ Faculty of Social Sciences \\ Universitas Negeri Malang \\ Malang, Indonesia
}

\begin{abstract}
Madura Island has the most potential for the development of salt ponds in Indonesia. The ponds are managed by the community and state-owned salt company (called $P T$ Garam). This study aimed to determine the management of ponds, traditions, and the economic rhythm of the community. The study employed a qualitative descriptive approach. The methods used for data collection were in-depth interviews and observations. Research results: during the dry season, the ponds are used as salt ponds around 4 months at most (June, July, August, and September). Every month, the harvest is 3-4 times on average. During the rainy season, each pond of PT Garam is left as it is; however, in the economic rhythm of the farmers, the ponds are used for fish farming, some of which are milkfish or shrimp. Some of the farmers catch the fish in the sea using rods, nets, or fishing gears for small fish (anchovies, squid, shrimp). Accordingly, the people of Sumenep and Pamekasan traditionally and hereditarily use a fishing tool called "pagan", while in Sampang Regency they catch the fish using "onjem". Moreover, people are trading in their area or in other areas.
\end{abstract}

Keywords: mina salt ponds, tradition, economic rhythm

\section{INTRODUCTION}

Mina salt is a product of an industry and also supply for various other industries. The traditional and modern fishery product processing industries use mina salt as a supply material for processing their fishery products. Mina salt is utilized to preserve, to enhance flavor, and to improve the appearance and texture of fish meat. Traditional processing industries using mina salt are the salted fish processing industry, pindang (boiling the fish in salt and spices), and fermented fish products, whereas the modern processing industry uses the salt to manufacture diversified processed products.

The use of mina salt in Indonesia is generally to meet consumption and industrial needs. In 2013, based on the balance of mina salt, the national need for consumption reached 1.4 million tons (of which around 500 thousand tons were imported), while the needs of the national salt industry reached 1.8 million tons (all were imported). To reduce dependency on imports, the Government, through the Ministry of Economy, launched national salt self-sufficiency through 3 (three) program strategies: extensification, intensification, and revitalization of salt ponds. Through these strategies, it is expected that the number of productive salt-pond areas is increased and the development of salt production technology will improve the quantity and quality of mina salt [1].

Considering the potential and production of mina salt for the people of Madura Island, the people's welfare improvement must be prioritized. As of today, the mina salt farmers in Madura Island still experience fluctuating economic rhythm, regardless the fact that the government policy in an effort to improve the salt farmers' welfare has declared the National Mina salt self-sufficiency at the end of 2010 and the national empowerment program of small salt-business (also called 'PuGaR') has been implemented since 2011[2], [3].

The implementation of $P u G a R$ in 2011 coincides with the stipulation of Presidential Regulations no. 32 of 2011 concerning the Master Plan for the Acceleration and Expansion of Indonesian Economic Development (MP3EI). If these two policies are integrated into a mutually reinforcing framework, it 

is expected that they can improve mina salt farmers' lives [4], [5]. For now, however, an effort to improve the salt farmers'economy is needed.

Salt manufacturing centers are concentrated on the islands of Java and Madura, whose areas respectively cover 10,231 Ha and 15,347 Ha. The other salt manufacturers are located in West Nusa Tenggara, South Sulawesi, and Sumatra, covering the areas of 1,155 $\mathrm{Ha}, 2,040 \mathrm{Ha}$, and 1,885 $\mathrm{Ha}$ respectively. Salt productions are mostly managed by the people traditionally [6].

TABLE I. SALT QUALITY BASED ON NACL

\begin{tabular}{|c|c|c|}
\hline Quality I & $\mathrm{NaCl}>98 \%$ & $\begin{array}{c}\text { Maximum Water } \\
\text { Content } 4 \%\end{array}$ \\
\hline Quality II & $94.4<\mathrm{NaCl}<98 \%$ & $\begin{array}{c}\text { Maximum Water } \\
\text { Content } 5 \%\end{array}$ \\
\hline Quality III & $\mathrm{NaCl}<94 \%$ & Water Content $>5 \%$ \\
\hline
\end{tabular}

Changes in the area of Mina salt ponds affect the improvement of the community's economy in Madura Island [7]. Government policies and community behavior are essential in maintaining the sustainability of Mina salt ponds in Madura Island. Regarding the ponds' management rhythm, in the dry season the ponds are used for salt ponds (around AprilOctober); in the rainy season (around November-March), there are ponds used for fish (mina) and shrimp, but most of the fishponds are left without being used maximally. Madurese people prefer to fish in the sea in the rainy season to keeping fish in ponds that will require a long time to farm. The type of fish kept in ponds is usually the milkfish for the traditional ceremony of "Nyadar".

According to the farmers, ponds that are used for fishpond extensification with artificial feed will cause pollution, and affect the quality of salt produced in the dry season. Therefore, in the rhythm of their economy, high income is earned during the dry season (salt season) while low income is earned during the rainy season (fish season). Since ponds exploitation can interfere with the sustainable management of the Mina salt pond area, they choose to improve their economy by fishing in the sea using the traditional tools called "onjem" and "pagan". Therefore, it is crucial to understand their rhythm and traditions to improve the economy of the Mina Salt pond farmers in Madura.

\section{METHOD}

This research employed a descriptive qualitative approach. To collect the data, the techniques used are (1) observation, aiming to find out: the cultural ecology of the Madurese people, the prospects for managing the Mina salt ponds and the roles performed by the government and the community; (2) indepth interviews; and (3) documentation studies to gather important information relating to salt farmers.
The main data source in this study was the community of mina salt pond farmers in Kalianget and Saronggi Districts in Sumenep Regency, in Sampang and Sreseh Districts, Sampang Regency, as well as in Gelis and Pedemawu Subdistricts in Pamekasan Regency. To analyze the research data, an interactive analysis model developed by Miles and Huberman (2002) was selected. The analysis includes three stages: (1) data reduction, at this stage the researcher conducted the process of selection, simplification, abstraction, and transformation of data obtained from the field; (2) the reduced data were presented according to the topic and subject matter in order to help the researcher in interpretation; and (3) drawing conclusions.

To ensure the validity of the data obtained during the research activities, several criteria are used: (1) degree of trust, to fulfill this criterion, the researchers conducted in-depth observations especially on ecological conditions; (2) disparity, to fulfill this criterion, the researcher attempted to describe the main problem under study thoroughly, carefully, in detail, and in-depth, so that the data obtained by the interpretation of the researcher can be distinguished; (3) dependency, to meet the accuracy of the data, the researcher conducted a careful reexamination of the components, processes, and results of the study; and (4) certainty, to meet this criterion, the researchers sought assistance from colleagues from Sampang, Pamekasan and Sumenep districts in the form of peer discussions to obtain complete and accurate information.

\section{RESULTS AND DISCUSSION}

The success of making salt is largely determined by the quality of seawater as the main raw material. The determining factor is that the land as a place to evaporate seawater must meet the elements of the soil's composition and structure which does not easily absorb water. Another determining factor is the climate, which is associated with solar and wind irradiation, both of which are very influential in the evaporation process in the process of making salt [8], [9]. The factors affecting salt harvest increase are soil, water, wind, and solar heat. The faster the soil hardens, the faster the salt will form. Soft clay affects the length of time in which salt can crystallize [10]. Clay soil mixed with sand crystallizes faster and salt forms more quickly.

Since 2011, the use of technology for salt processing has been implemented in Madura at 5 (five) locations spread across Sampang, Pamekasan and Sumenep Regencies. The Sampang Regency group of Al Hidayah salt farmers with the Taman Mina salt trademark received the technology package. In Pamekasan Regency, the Cempaka group with the Nifana trademark, Puspa Marina group with the Mina salt Nusantara trademark, and the Blue Laut IKM group with the Sari Madura trademark received the package. In Sumenep Regency, the 
Sumber Hasil salt farmers group with the Segoro Madu trademark also received one.

The condition of the pond area and the number of workers spread across Sampang, Pamekasan, and Sumenep are illustrated in the following fig:

The Chart of Farm Area vs. Number of Workers in Madura

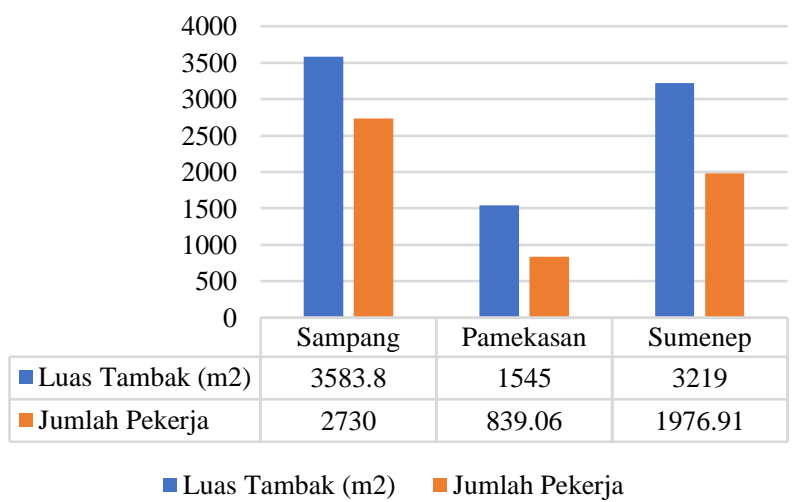

Fig. 1. The Chart of Pond Area and Number of Workers in Sampang, Pamekasan and Sumenep Regencies

From fig 1, it can be concluded that Sampang Regency has the most extensive ponds, the highest number of people working in ponds, and salt processing among the three regencies.

The Chart of Farm Area vs. Number of Workers in Sampang Regency

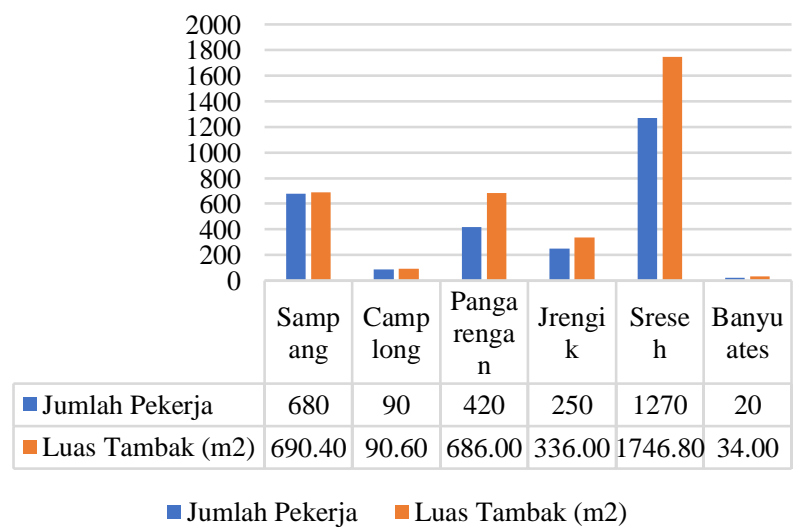

Fig. 2. The Chart of Pond Area and Number of Workers in Sampang District

From fig 2, it can be concluded that Sreseh and Sampang Districts have the most extensive ponds, the highest number of people working in ponds, and salt processing in Sampang Regency.

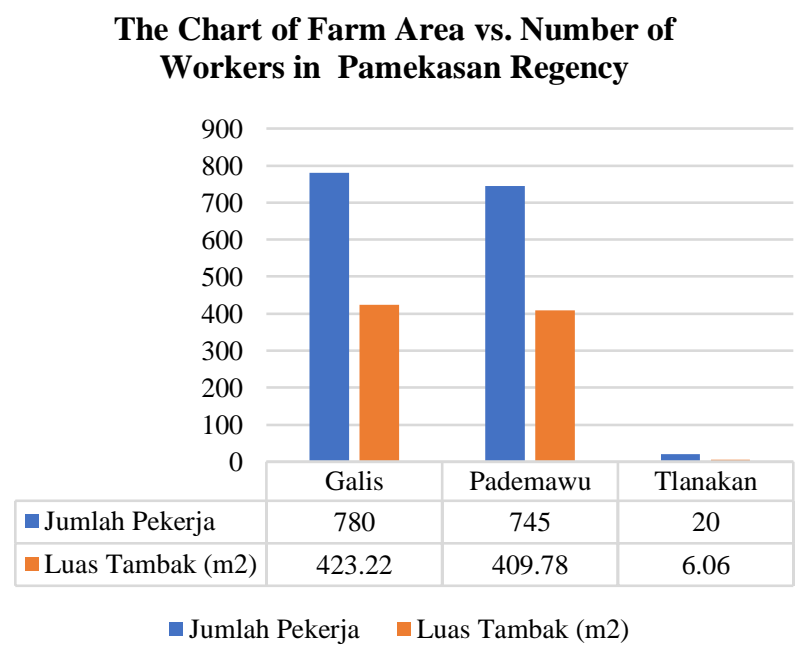

Fig. 3. The Chart of Pond Area and Number of Workers in Pamekasan Regency

From fig 3, it can be concluded that Galis and Pademawu Districts have the most extensive ponds, the highest number of people working in ponds, and salt processing in Pamekasan.

\section{The Chart of Farm Area vs. Number of Workers in Sumenep Regency}

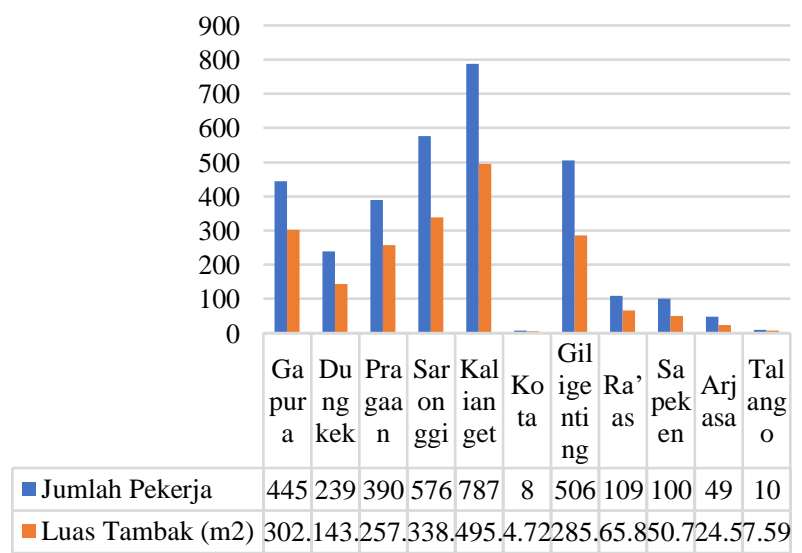

- Jumlah Pekerja $\quad$ Luas Tambak (m2)

Fig. 4. The Chart of Pond Area and Number of Workers in Sumenep Regency

From fig 4, it can be concluded that Kalianget and Saronggi Districts have the most extensive ponds, the highest number of 
people working in ponds, and salt processing in Sumenep Regency.

\section{A. The Results of the Interview with Pak Dony (Pinggir Papas Village, Sumenep)}

Pak Dony has a wife and 3 children; he works in a salt pond. He works at Pak H. Osen who has 6 salt pond locations. Each location is 1 ha $(1000 \mathrm{~m} 2)$ wide. In the locations, the average harvest per month is done 3 times, around 120 sacks ( $25 \mathrm{~kg}$ for each sack). The net sales of salt are reduced by collection costs, transporting and vehicles costs, etc. For the rest of it, 1/3 is for employees (Pak Dony) and 2/3 is for the landowner (Pak H. Osen). Salt farmers who work in people's salt ponds earn an average of 4 million Rupiahs per month, and those who work at PT Garam earn an average of 2.5 million Rupiahs per month; usually, the fee is paid weekly.

In Pinggir Papas Village, Sumenep, all of its areas are utilized as salt ponds. Some of them belong to PT Garam and some are owned by the people, which have existed since the Dutch colonialization era; PT Garam, however, started in 1928 [11]. Water pumps are partly built since the Dutch colonialization era. In the Japanese colonialization era, these lands were ruled by Japan. Since the independence day, the salt ponds have been managed by the government, handled by SOEs. In its development, the lands owned by the Water Resources Office have been handed over to PT Garam to be managed as salt ponds.

The salt harvest season is in June, July, August, and September. During this time, Sumenep people who are also experts in salt pond management do not only work in the Sumenep area; some of them go to other areas, such as Benowo (Surabaya), Sidoarjo, and Pasuruan. After the season is over, they will return to their villages in Sumenep.

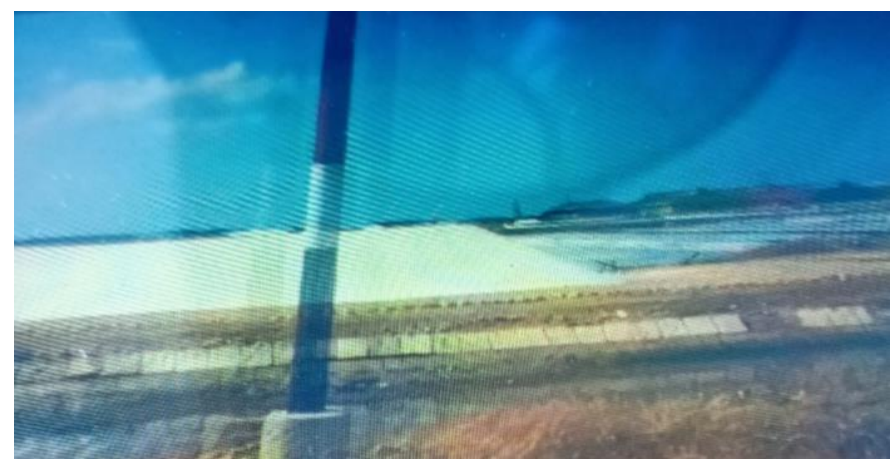

Fig. 5. Piles of Salt Harvest in Sumenep

There are 4 types of salt processing produced, they are KW I, KW II, KW 3 (KW stand for 'quality', in Indonesian) and premium quality [12]. The quality is very much related to the basic arrangement of the ponds. For those left naturally, they produce $3 \mathrm{KW}$ salt; and for ponds that are lined with tarpaulins and polybags with a thickness of 0.5 , can last up to 5 years. To get the premium quality, the required conditions are: the land must be clean, the water must be $25 \mathrm{~B}$, no ramps on the land, its minimum thickness is $5 \mathrm{~cm}$, and its minimum age is 10 days [13].

\section{B. Interview Results with Pak Andi, An Owner of Mina Garam Pond}

Pak Andy has a 1 ha pond. In a salt season, he will harvest around 80 tons. The price of salt produced ranges from 500,000 - 3,000,000 Rupiahs. High prices greatly depend on the middlemen bringing the harvested salt to the salt industry in Surabaya. Usually, the middlemen do not pay the farmers directly; they pay the salt farmers in 1 or 2 weeks after the salt is brought to the industry. The middlemen in Pinggir Papas village use trucks as their transportation.

After the end of the salt season, the farmers will use their ponds for spreading the milkfish seeds. The milkfish harvest will be used during the "Nyadar" traditional ceremony held 3 times a year. Aside from farming fish in ponds, they also trade, hunt for crabs, and become fishermen.

The salt ponds in Sumenep, which are owned by PT Garam during the rainy season, are left without processing, and this also occurs to some of the farmers' salt ponds; although some of them are used for farming milkfish. 5 real of milkfish seeds ( 25 thousand milkfish seeds) are usually spread in Pak Andy's pond. One real cost 5,500 Rupiahs. The milkfish is selected because the community will hold a "nyadar" feast in the Full Moon in July and they use milkfish as the main food in the traditional ceremony.

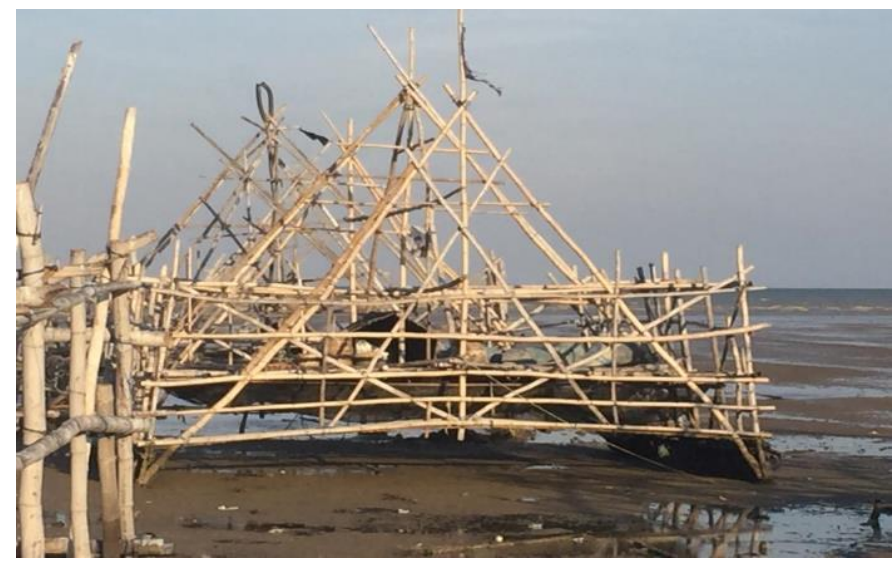

Fig. 6. Pagan as a Tool for Catching Small Fish

During the rainy season, some of the farmers catch the fish in the sea using rods, nets, or fishing gears for small fish (anchovies, squid, and shrimp). Accordingly, the people of Sumenep and Pamekasan traditionally and hereditarily use a fishing tool called "pagan", while in Sampang Regency they 
catch the fish using "onjem". Pagan is a small house made of bamboo assembled like a house, having a place to shelter, and most importantly, it has lights installed to 'invite' the fish; and underneath, a net with a size of $10 \times 10 \mathrm{~m}$ is installed to catch fish, of which the net hole is $2 \mathrm{~mm}$ due to the small size of the fish. During the fishing season, this tool is placed in the middle of the sea, in about $3 \mathrm{~km}$ from the seafront; and when it is not a fishing season, the pagan will be brought to the seashore.

\section{Results of the interview with Pak Suparman, the Ship Owner}

Ships are used as taxis in controlling the pagan. In every ship, there are 8 people deployed on 8 pagans. They leave in the evening around 8 p.m. in Western Indonesian Time, and they return at around 5 in the morning. They have been working in groups for a long time and generations.

Based on the interview results with Pak Edy, he is a salt farm worker in the dry season and is a fisherman using pagan in the rainy season. When catching fish using pagan, they lift the net 5 times during one night. Each time the net is lifted, an average of $3 \mathrm{~kg}$ of anchovies, squid, and small mackerel fish are caught. After arriving at the beach in the morning, the fishermen wait for the middlemen and are ready with the price of squids: Rp 40,000 / kg, anchovies: Rp 10,000 / kg, and mackerels: Rp 3,000 / kg.

Aside from being a mina salt farmer, there are also Sumenep people working at PT Garam. The results of interviews conducted with Pak Moh. Husen, who graduated from high school, show that he worked at PT Garam in 19782011. Pak Husen works as a crystallization committee. In PT Garam, there are the Crystallization Unit, Election Unit, Security Unit, Finance Unit, Workshop Unit, and Warehouse Unit. In the Crystallization Unit, there are Tank Foreman, Weigh Foreman, Bag Foreman, and workers for carrying goods. Pak Husen gets a monthly salary from PT Garam of Rp 5,000,000; he also received electricity, housing, and transportation benefits.

For Madura Island, in particular, the main problem is how to raise the potential of mina salt resources to become one of the main components of economic resources and how to accelerate and expand the mina salt farmers' marketing network as an effort to increase their economy.

\section{CONCLUSION}

During the dry season, the ponds are used as salt ponds for 4 months (June, July, August, September) at most. Every month, the harvest is done 3-4 times on average. During the rainy season, each pond of PT Garam is left as it is; however, in the economic rhythm of the farmers, the ponds are used for fish farming, some of which are milkfish or shrimp. Some of the farmers catch the fish in the sea using rods, nets, or fishing gears for small fish (anchovies, squid, shrimp). Accordingly, the people of Sumenep and Pamekasan traditionally and hereditarily use a fishing tool called "pagan", while in Sampang Regency they catch the fish using "onjem". Moreover, people are trading in their area or in other areas.

The priority needs that must be developed by the government to improve people's economy are structuring and developing irrigation system infrastructure, water pumping systems equipped with filtering, road networks to salt ponds, warehousing facilities and salt processing units as well as packaged houses for processed people's salt and marketing.

\section{REFERENCES}

[1] A. Amri, "Belasan Ribu Hektare Lahan Garam Belum Tergarap," Kontan.co.id, 2009. [Online]. Available:

https://industri.kontan.co.id/news/belasan-ribu-hektare-lahan-garambelum-tergarap-1. [Accessed: 10-Jun-2010].

[2] KP3K, Pemberdayaan Usaha Garam Rakyat (PUGAR). Indonesia: Kementerian kelautan dan Perikanan Republik Indonesia, 2011.

[3] KP3K, Pedoman Pelaksanaan Program Nasional Pemberdayaan Masyarakat Mandiri Kelautan dan Perikanan Tahun 2011. Indonesia: Kementerian kelautan dan Perikanan Republik Indonesia, 2011.

[4] Pelita, "Swasembada garam terancam akibat tata niaga buruk," Pelita.or.id, 2010.

[5] Kementerian Kelautan dan Perikanan, "Jalan menggapai swasembada garam 2015," Mina Bahari, pp. 20-21, 2011.

[6] D. Purbani, "Proses Pembentukan Kristalisasi Garam," Pus. Ris. Wil. Laut dan Sumberd. Nonhayati, pp. 1-17, 2000.

[7] W. . Jati and C. Purwoko, "Ironi Industri Garam Nasional," YPTrading, 2010. [Online]. Available:

http://www.yptrading.co.id/artikel/cetakpdf/1/ironi-industri-garamnasional. [Accessed: 21-Jun-2010].

[8] E. Prasetyaningsih, "Industri garam (NaCl)," Wikidot, 2008. [Online]. Available: http://kuliah.wikidot.com/garam. [Accessed: 02-May-2011].

[9] E. . Aprilia and N. . Ali, "Produksi garam merosot," Koran Tempo, Jakarta, 07-Jan-2011.

[10] G. I. Pamuji and M. F. Anwar, "Studi laju pengeringan garam," pp. 14.

[11] A. Mahdi, "Upaya peningkatan produksi dan kualitas garam nasional," $B U M N$, 2007. [Online]. Available:

http://portal.bumn.go.id/garam/modules/?id=papr\&svr=s05\&idmod=70 \&idBUMN=GRAM. [Accessed: 10-Jun-2010].

[12] V. A. Mayasari and R. Lukman, "Studi Peningkatan Mutu Garam dengan Pencucian,” ITS Library, Surabaya, 2010.

[13] T. Kurniawan and B. V. I. Yanti, "Efek Kombinasi dari Perubahan Iklim, Limbah dan Krisis Moneter di Sektor Perikanan," in Seminar PIT VI ISOI 2009, 2011. 